\title{
Wykorzystywanie zwłok więźniów do badań w instytutach anatomicznych w III Rzeszy
}

DOI: http://dx.doi.org/10.12775/SIT.2014.009

W 1998 roku obiegła Polskę informacja o niezwykłym i szokującym znalezisku w Muzeum Historii Naturalnej w Wiedniu. W zbiorach muzealnych tej jednostki odkryto 15 spreparowanych ludzkich czaszek, zakwalifikowanych jako „czaszki podludzi”, które jak wynikało z ustaleń muzealników, przybyły tam z Polski w okresie okupacji hitlerowskiej. W toku śledztwa prokuratorzy IPN stwierdzili, że kości te pochodziły z Poznańskiego Instytutu Anatomicznego. W tym miejscu należy zastanowić się, skąd czerpano „materiały badawcze” tego i innych instytutów medycznych, co z nimi robiono i w jakich celach.

\section{Zwłoki ofiar jako preparaty badawcze}

W XX wieku nastąpił ogromny skok cywilizacyjny związany z rozwojem wszystkich dziedzin nauki. Mimo tragedii i oczywistej szkodliwości dwóch wojen światowych wielu naukowców przyznaje, że zarówno badania związane $z$ potrzebami wojennymi, jak i te prowadzone w czasie wojny paradoksalnie wpłynęły na rozwój nauk technicznych i przyrodniczych. Szybki rozwój medycyny nie byłby możliwy bez odkryć w dziedzinie chemii i fizyki, ale także szerokiego 
dostępu do materiałów badawczych, umożliwiających dogłębne studiowanie ludzkiej anatomii i fizjologii. W przypadku medycyny, podstawowym materiałem badawczym w okresie trwania III Rzeszy (z wyłączeniem więźniów obozów zagłady i pracy) były zwłoki osób zmarłych w obozach pracy, szpitalach i przytułkach, a także więźniów, na których wykonano wyroki śmierci. Niemieckie instytuty anatomiczne w okresie międzywojennym do celów badawczych i edukacyjnych posługiwały się zwłokami osób, na których przeprowadzono egzekucję, a także ciałami osób bezdomnych i bezimiennych. Jak wynika $z$ korespondencji Instytutu Anatomicznego w Halle, w latach 1923-1933 z powodu zniesienia kary śmierci w Saksonii - Anhalt, jednostka naukowa, nie otrzymywała do badań zwłok straconych więźniów, co w obliczu niedoboru właściwych preparatów bezpośrednio utrudniało proces szkolenia studentów medycyny ${ }^{1}$. $Z$ podobnymi problemami borykali się dziekani innych instytutów medycznych, jak bowiem wynika $z$ szacunków, w okresie od końca I wojny światowej do 1933 roku na terenie Niemiec wykonano zaledwie 20 egzekucji. W obliczu tak poważnych problemów wykładowcy kształcili młodą kadrę na ciałach osób zmarłych w przytułkach, noclegowniach, których jednak nie było wiele, i organizmach zwierząt takich jak świnie, psy lub małpy. Dużą zmianę przyniosły rządy NSDAP, która przywróciła karę śmierci na terenie całego państwa, podnosząc statystyki do 12000 wyroków śmierci wykonanych w centralnych miejscach straceń przez ścięcie lub powieszenie (do końca trwania II wojny światowej) ${ }^{2}$. W tym okresie podstawową formą wykonania egzekucji było ścięcie gilotyną ${ }^{3}$. Praktykowano też

${ }^{1}$ Bundesarchiv (dalej: BA), nazwa zespołu: Informationsdienst des Reichsministers der Justiz, alt R 22/1315, k. 240 f.

2 T. Waltenbacher, Zentrale Hinrichtungsstätten, Der Vollzug der Todesstrafe in Deutschland von 1937-1945. Scharfrichter im Dritten Reich, Berlin 2008, s. 4. Jak wskazuje Daniel Gerould, liczba ta w okresie 1933-1945 mogła wynosić nawet 16 500. D. Gerould, Historia gilotyny. Legenda i morał, tłum. A. Kruczkowska, Gdańsk 1996, s. 199.

${ }^{3}$ Do 1938 roku w III Rzeszy trwał okres ujednolicenia narzędzi śmierci. Ostatecznie zrezygnowano $z$ topora na rzecz stosowanej w niektórych landach 
powieszenie i rozstrzelanie ${ }^{4}$. Zgodnie $z$ niemieckim prawem osoby najbliższe skazanego na śmierć więźnia należało poinformować o wyroku, oczekiwaniu na decyzję Führera w sprawie prawa łaski, a w przypadku negatywnej odpowiedzi z Kancelarii Rzeszy przypominano o konieczności przeprowadzenia skromnych obrzędów pogrzebowych po wykonaniu wyroku. Ponadto zagwarantowano członkom rodziny możliwość przewiezienia zwłok straconego więźnia z zakładu karnego do wskazanego miejsca pochówku. Nadzór nad tymi czynnościami miała sprawować właściwa władza policyjna. Zgodnie z treścią Rozporządzenia Ministra Sprawiedliwości III Rzeszy z dnia 19 lutego 1939 roku w sprawie wykonywania wyroków śmierci na terenie kraju rodzina skazańca miała prawo określenia trybu postępowania $\mathrm{z}$ jego zwłokami wyłącznie do czasu wykonania wyroku. W przypadku braku terminowej odpowiedzi uprawnionych krewnych domniemywano, że rodzina nie wyraża chęci opieki nad ciałem zmarłego więźnia, co w myśl przytoczonego rozporządzenia wiązało się $\mathrm{z}$ obligatoryjnym poinformowaniem naczelnika właściwego instytutu anatomicznego o terminie egzekucji i braku woli krewnych do odbioru zwłok. Wyłącznie w takim przypadku ciało mogło zostać przekazane na cele badawcze. Po wykonaniu egzekucji sporządzano protokół z jej przebiegu, wpisując w odpowiedniej rubryce informacje np. „zwłoki zostały wykorzystane do celów anatomicznych" ${ }^{5}$. Hipotetycznie istniała także możliwość odmowy ich przyjęcia przez placówkę badawczą, co w ostateczności zobowiązywało miejscową jednostkę policji do przeprowadzenia skrom-

gilotyny. BA, nazwa zespołu: Informationsdienst des Reichsministers der Justiz, alt R 22/1317, k. 93.

${ }^{4} \mathrm{~W}$ Niemczech przed wybuchem II wojny światowej egzekucje przez powieszenie należały do rzadkości. Tylko jeden wykonawca kary śmierci miał doświadczenie w jej wykonywaniu. Co ciekawe, Johann Reichhart przeszkolił w tym zakresie wszystkich pozostałych niemieckich katowskich mistrzów. Wraz $z$ wybuchem wojny metoda ta rozpowszechniła się i była permanentnie stosowana - zwłaszcza w Kraju Warty i Generalnym Gubernatorstwie. Podobna ewolucja nastąpiła w odniesieniu do egzekucji przez rozstrzelanie. BA, nazwa zespołu: Informationsdienst des Reichsministers der Justiz, alt R 22/1317, k. 218, 233.

${ }^{5}$ T. Waltenbacher, op.cit., s. 211. 
nego pochówku ciała straconego więźnia ${ }^{6}$. Mimo zdecydowanego statystycznego wzrostu wykonywanych wyroków śmierci w latach 1933-1939 obowiązujące przepisy utrudniały, a wręcz uniemożliwiały prowadzenie badań na straconych więźniach, których zwłoki rodzina chciała po egzekucji pochować. $Z$ całą pewnością część $z$ nich pozostawała $w$ miejscach straceń, lecz była to liczba niewystarczająca do zaspokojenia potrzeb medycznych placówek badawczych. Jeszcze pół roku przed wybuchem II wojny światowej wydziały medyczne uniwersytetów w Kolonii i Greifswaldzie borykały się z poważnymi trudnościami badawczymi i dydaktycznymi, ponieważ uprawnieni członkowie rodzin w zdecydowanej większości wyrażali chęć pochówku straconych więźniów. Brak materiałów sekcyjnych negatywnie wpływał na proces kształcenia młodych lekarzy. Władze uniwersytetów winą za przytoczoną sytuację obarczyły niekorzystne dla instytutów medycznych więzienne przepisy prawne faworyzujące krewnych więźniów skazanych na śmierć. Na spotkaniu władz ośrodków naukowych $\mathrm{z}$ administracją w Ministerstwie Sprawiedliwości III Rzeszy przedstawiono postulaty zmiany tego prawa. Domagano się wprowadzenia zasady prawnej umożliwiającej dokonywania sekcji zwłok na straconych więźniach, a także tego, by badania obdukcyjne następowały przed ich wywiezieniem i wydaniem ciał uprawnionym członkom rodziny ${ }^{7}$. Na skutek licznych konsultacji

${ }^{6}$ BA, nazwa zespołu: Informationsdienst des Reichsministers der Justiz, alt R 22/1317, k. 65. Powyższe zasady obowiązywały przede wszystkim obywateli niemieckich. IPN Oddziałowa Komisja Ścigania Zbrodni Przeciwko Narodowi Polskiemu w Gdańsku (dalej: OK Gd.), sygn. S 74/02/Zn, t. 14, Rozporządzenie Ministra Sprawiedliwości Rzeszy z dnia 19.02.1939 r. w sprawie wykonywania wyroków śmierci, k. 2680-2683, IPN OK Gd., S 74/02/Zn, t. 14, Zarządzenie Ministra Sprawiedliwości Rzeszy z dnia 17.01.1945 r. w sprawie wykonywania wyroków śmierci w czasie wojny, k. 2690-2692.

7 BA, nazwa zespołu: Informationsdienst des Reichsministers der Justiz, alt R 22/1070, k. 325. W marcu 1943 roku niemieckie rozporządzenie dokonało kolejnych zmian w zasadach wydawania zwłok. Rodzina zabitego więźnia posiadającego obywatelstwo niemieckie na wniosek miała prawo zabrać ciało i przygotować skromne czynności pogrzebowe na najbliższym cmentarzu. Istniała też alternatywa spopielenia zwłok. Takich uprawnień pozbawiono krewnych straconych Polaków i Żydów podlegających „polskiemu prawu karnemu” (ustawodawca zapewne miał na myśli przepisy karne Generalnej Guberni). Rodziny więźniów straconych za przestępstwo szeroko rozumianej zdrady, by 
wprowadzono zakaz otwierania trumien, w których znajdowali się ścięci na gilotynie więźniowie. Równocześnie instytuty anatomiczne zdobyły prawo do przeprowadzenia badań pośmiertnych na ciałach ofiar. Obdukcji należało dokonać w najbliższej medycznej jednostce naukowej w czasie od dwóch do trzech godzin po egzekucji, po których upływie zwłoki w zamkniętej trumnie przekazywano rodzinie do celów pochówku ${ }^{8}$.

Miejsca straceń i cele śmierci zbudowane były najczęściej z dwóch pomieszczeń. W pierwszym dokonywano np. dekapitacji, a w drugim znajdowała się trumna ${ }^{9}$, w której składano zwłoki ofiary ${ }^{10}$. Jak wspomniano, w przypadku braku zainteresowania rodziny losami ciała, kierowano je $z$ więziennych kostnic do instytutów anatomicznych lub po krótkiej sekcji, na wniosek następców prawnych, przekazywano organom policyjnym w celu przygotowania pogrzebu. W pierwszym przypadku trumny transportowano ciężarówkami do położonych $\mathrm{w}$ pobliżu centralnych miejsc straceń instytutów naukowych, których władze pokrywały związane $z$ tym koszty. Na ciałach zdekapitowanych, powieszonych, a w szczególności rozstrzelanych skazańców po niezwłocznym zabezpieczeniu materiału badawczego w roztworze formaliny, dokonywano autopsji częściowej lub całkowitej ${ }^{11}$. W przypadku rozstrzelanych pilne zabiegi konserwacyjne musiały mieć miejsce na skutek uszkodzeń wielonarządowych spowodowanych licznymi ranami postrzałowymi, co narażało zwłoki na ich przyspieszony i nieodwracalny rozkład. Procesy badawcze prowadzone na ciałach straconych więźniów wymagały, jak wskazywał Uniwersytet w Kolonii, odpowiednich ilości środków konserwujących, którymi balsamowano je już w zakładzie karnym albo w instytucie. Do tych czynności stosowano formalinę, glicerynę, kwas karbolowy i alkohol. Uniwersytet zwracał uwagę, że wykorzystanie zwłok do celów badawczych może nastąpić do-

uzyskać dostęp do ciała ofiary, musiały zdobyć aprobatę tajnej policji państwowej - Gestapo.

8 Ibidem, alt R 22/1315, k. 137.

${ }^{9}$ Zdarzało się, że władze więzienne dostosowywały pokój sąsiadujący z celą straceń do celów prosektoryjnych.

10 T. Waltenbacher, op.cit., s. 211.

${ }^{11}$ Ibidem. 
piero po upływie 30 minut. Placówka badawcza podkreślała także znaczny koszt związany z zabezpieczeniem zwłok ofiar dokonanych egzekucji. W celu przeprowadzenia kilkugodzinnych sekcji zwłok badacze musieli je natychmiast zabezpieczać, narażając się często na straty finansowe $z$ tym związane. Miało to miejsce zwłaszcza w sytuacji, gdy po przeprowadzeniu dopuszczalnej, zgodnej z prawem trzygodzinnej autopsji rodzina odbierała $z$ aresztu śledczego zabezpieczone już wstępnie ciała dla celów naukowych. W takim przypadku koszty zbędnej konserwacji obciążały ośrodki badawcze, których $z$ powodu ciężarów wojennych zainteresowany uniwersytet nie był w stanie ponieść ${ }^{12}$.

Kolejne źródło zaopatrywania niemieckich instytutów anatomicznych w materiał badawczy, zwłaszcza w okresie II wojny światowej, stanowiły zwłoki osób zmarłych w szpitalach i przytułkach, które na mocy zarządzeń wysokiej rangi urzędników Ministerstwa Spraw Wewnętrznych oraz Ministerstwa Zdrowia III Rzeszy przeznaczano wyłącznie do celów badawczych. Zgodnie z treścią zarządzenia Kierownika Okręgu Zdrowia w Okręgu Rzeszy Gdańsk-Prusy Zachodnie w sprawie dostaw i transportu zwłok dla celów anatomicznych nakazano przekazywać zakładom uniwersyteckim zwłoki zmarłych niemających żadnych krewnych, względnie takich, których krewni nie wrażali chęci ich pogrzebania, zaznaczając, że w grę wchodzą także ciała dzieci oraz zwłoki, na których przeprowadzono już wcześniej sekcję klatki piersiowej lub brzucha. W uzasadnieniu wskazano, że działania te są niezbędne i bezwarunkowo konieczne w celu skutecznego kształcenia kadry medycznej, a co za tym idzie, polepszenia opieki zdrowotnej całej ludności ${ }^{13}$. Wraz z nasilającą się w III Rzeszy polityką eksterminacyjną, w obozach koncentracyjnych i przytułkach dla osób niepełnosprawnych zamknięto setki tysięcy

12 BA, nazwa zespołu: Informationsdienst des Reichsministers der Justiz, R 22/1478, k. 231. Władze Instytutu Anatomicznego przy Uniwersytecie w Kolonii proponowały obciążać tym kosztem rodzinę straconego więźnia, która ostatecznie zdecydowała się odebrać zakonserwowane ciało.

13 Archiwum Państwowe w Gdańsku (dalej: AP Gd.), Państwowy Szpital dla Nerwowo i Psychicznie Chorych w Starogardzie Gdańskim Kocborkowie, sygn. 2830/163, k. 85; M. Tomkiewicz, P. Semków, Profesor Rudolf Spanner 1895-1960. Naukowiec w III Rzeszy, Gdynia 2010, s. 47. 
ludzi „drugiej kategorii”. Ofiary systemu totalitarnego, które masowo umierały na skutek niedożywienia, chorób, wycieńczającej pracy lub były świadomie uśmiercane, stanowiły niewyczerpalne źródło „materiału ludzkiego” ${ }^{14}$. Jeśli chodzi o potrzeby badawcze Gdańskiego Instytutu Anatomicznego, wiadomo, że Okręgowy Zakład Zdrowotno-Opiekuńczy w Kocborkowie stał się jednym z głównych dostawców zwłok ludzkich wykorzystywanych do szkolenia stale powiększającej się liczby studentów medycyny pomorskiej placówki badawczej. $Z$ czasem ciała zmarłych w szpitalu pacjentów stały się swoistym przedmiotem obiegu gospodarczego o ustalonej cenie i wartości. W pierwszym okresie II wojny światowej Gdański Instytut skupował je po cenie $15 \mathrm{RM}$, lecz z czasem ich cena spadała, osiągając ostatecznie poziom 9 RM. Należy przy tym zauważyć, że trzecią część wartości powyższej kwoty inkasowali pracownicy kocborskiego zakładu, a pozostałe dwie trzecie wpływały do jego kasy, powiększając tym samym budżet tej placówki. Pełnomocnik Gauleitera Forstera, odpowiedzialny m.in. za wymiar sprawiedliwości, doktor Willibald Wiers-Kaiser napisał 6 sierpnia 1941 roku, że proponowana za zwłoki cena znacznie odbiega od tych proponowanych innym instytutom anatomicznym na terenie III Rzeszy (20 RM), co sprawia, że jest ona nie do przyjęcia ${ }^{15}$. Ponadto instytuty anatomiczne ponosiły dodatkowe koszty związane $z$ zakupem trumien (17,50 RM za sztukę), a także transportem straconych więźniów i ich kremacją (61,60 RM za ciało) ${ }^{16}$.

${ }^{14}$ M. Tomkiewicz, P. Semków, op.cit., s. 47.

15 AP Gd., Państwowy Szpital dla Nerwowo i Psychicznie Chorych w Starogardzie Gdańskim Kocborkowie, sygn. 2830/163, k. 3, 162. Z ustaleń autorów publikacji Profesor Rudolf Spanner 1895-1960 wynika, że kierownik Katedry Anatomii prof. Spanner mógł wywierać presję na władze szpitala, pisząc listy, w których informował dyrekcję ośrodka w Kocborkowie o braku „materiału ludzkiego", prosząc o zwiększenie jego zaopatrzenia. IPN OK Gd., sygn. S 74/02/ Zn, t. 8, k. 1494-1495.

${ }^{16} \mathrm{O}$ ile w okresie międzywojennym instytuty anatomiczne cierpiały na niedobór ludzkich preparatów badawczych, to podczas wojny ich podaż przewyższyła popyt. Placówki te nie były w stanie magazynować takich ilości ciał, więc musiały na własny koszt (w przypadku braku wniosku osób uprawnionych) dokonać pochówku lub kremacji ofiar. BA, nazwa zespołu: Informationsdienst 
Zgodnie z oświadczeniem Eduarda von Bargena, przesłuchiwanego na okoliczności działalności Gdańskiego Instytutu Anatomicznego, zwłoki więźniów obozu zagłady KL Stutthof nie były pożądanym materiałem badawczym, ponieważ stan tych ciał uniemożliwiał wykorzystanie ich do celów naukowych ${ }^{17}$. Instytuty anatomiczne preferowały zwłoki ofiar straconych przez gilotynę lub powieszonych, gdyż ich uszkodzenia były znacznie mniejsze niż korpusy osób rozstrzelanych, bezdomnych i wycieńczonych morderczą pracą. Spostrzeżenie to potwierdzają przerażające statystyki, bowiem pośród zwłok odkrytych w piwnicach Gdańskiego Instytutu Anatomicznego doliczono się 148 ciał - w 82 przypadkach dobrze odżywione ofiary pozbawiono głowy przez dekapitację, kilka osób zmarło na skutek powieszenia lub uderzeń twardym, tępym narzędziem w głowę. W jednym przypadku stwierdzono śmierć przez rozstrzelanie ${ }^{18}$. Należy zaznaczyć, że obrót zwłokami osób straconych lub zmarłych w centralnych miejscach straceń, szpitalach, przytułkach i obozach zagłady stał się możliwy dzięki pozytywnej opinii Sądu Rzeszy, który orzekł, że „Z chwilą śmierci człowieka w żadnym razie nie powstaje prawo własności do ciała ze strony krewnych ani jakichkolwiek innych osób, a już na pewno nie stanowią one części majątku zmarłego i tym samym nie przechodzą na własność spadkobierców"19. Powyższe konstytutywne orzeczenie najwyższego sądu III Rzeszy wydano po burzliwej dyskusji prawnej nad materialnoprawnym charakterem zwłok ludzkich, która wybuchła w obliczu powracającej propozycji wsparcia gospodarki narodowej odzyskiwanym po śmierci pacjenta złotem dentystycznym. W następstwie tych rozważań interpretację prawną przedmiotowości ciała ludzkiego, wbrew obowiązującej myśli humanitaryzmu, rozcią-

des Reichsministers der Justiz, alt R 22/1317, k. 141f; ibidem, alt R 22/1318, k. 220 .

17 IPN OK Gd., syg. S 74/02/Zn, t. 4, k. 729.

${ }_{18}$ M. Tomkiewicz, P. Semków, op.cit., s. 79; IPN OK Gd., sygn. S 74/02/ Zn, t. 5, k. 894-954.

19 M. Tomkiewicz, P. Semków, op.cit., s. 64; S. Kłodziński, Z zagadnień „gospodarczej” eksploatacji zwłok ludzkich w Niemczech hitlerowskich, „Przegląd Lekarski” 1964, nr 1, s. 91-96. 
gnięto na wszystkie zwłoki ofiar totalitarnego ustroju, pozbawiając je poszanowania i jakiejkolwiek prawnej ochrony.

\section{Podział administracyjny instytutów anatomicznych i wyposażenie sal sekcyjnych}

Wraz z prawnym obowiązkiem przekazywania zwłok straconych więźniów zakładom medycyny, prace badawcze usprawniano, lokalizując instytuty anatomiczne w pobliżu miejsc straceń. Zgodnie z Rozporządzeniem Ministra Sprawiedliwości III Rzeszy z dnia 18 lutego 1939 roku w sprawie przekazywania zwłok osób straconych do niemieckich placówek naukowych, więzienie karne Berlin-Plötzense przypisano Instytutowi Anatomiczno-Biologicznemu Uniwersytetu Berlińskiego i Instytutowi Anatomicznemu Uniwersytetu w Greifswaldzie. Więzienie Karne w Dreźnie dostarczało materiały dla Instytutu Anatomicznego Uniwersytetu w Lipsku. Więzienie Karne w Frankfurcie nad Menem zaopatrywało Instytut Anatomiczny Uniwersytetu Frankfurckiego, Uniwersytetu w Gieben i Uniwersytetu w Marburgu. Więzienie Karne w Hamburgu-Stadt działało na potrzeby Instytutu Anatomicznego Uniwersytetu w Hamburgu, Uniwersytetu w Rostocku i Uniwersytetu w Kiel. Więzienie Karne w Kolonii zabezpieczało potrzeby Instytutu Anatomicznego Uniwersytetu w Bonn, Uniwersytetu w Münster i Uniwersytetu w Kolonii. Więzienie Karne w Królewcu zaopatrywało Instytut Anatomiczny Uniwersytetu w Królewcu. Więzienie Karne w Monachium-Stadelheim przypisano do Instytutu Anatomicznego Uniwersytetu w Monachium, Uniwersytetów w Erlangen, Würzburgu, Freiburgu, Heidelbergu i Tybindze. Więzienie Karne w Weimarze zaopatrywało w preparaty instytuty anatomiczne Uniwersytetów w Halle i Jenie. Więzienie Karne w Wolfenbüttel wspierało Instytut Anatomiczny Uniwersytetu w Getyndze. Więzienie Karne w Wiedniu zabezpieczało potrzeby Instytutu Anatomicznego Uniwersytetu Wiedeńskiego i Uniwersytetu w Graz. Więzienie Karne we Wrocławiu zapewniało materiały badawcze Instytutowi Anatomicznemu Uniwersytetu 
Wrocławskiego ${ }^{20}$. Po zajęciu Polski władze niemieckie stworzyły kolejne miejsca straceń - w Poznaniu i Gdańsku, które zaopatrywały Instytut Anatomiczny Akademii Medycznej w Gdańsku i Instytut Anatomiczny Uniwersytetu Rzeszy w Poznaniu ${ }^{21}$. Zaprezentowany podział administracyjny, zastosowany do medycznych jednostek naukowych, ustanowił Minister Sprawiedliwości III Rzeszy ${ }^{22}$, mimo to wciąż zdarzały się przypadki niedoboru materiałów badawczych w niektórych placówkach anatomicznych ${ }^{23}$. Wraz z podziałem niemieckich wydziałów i instytutów medycznych zmierzającym do efektywnego wykorzystywania działalności centralnych miejsc straceń, postanowiono także ujednolicić wyposażenie wszystkich sal prosektoryjnych. Od 1939 roku w każdej z nich musiały się znajdować dwa długie noże narządowe ${ }^{24}$, jeden długi nóż do cięcia mózgu, dwa małe preparacyjne noże, jeden nóż do golenia ${ }^{25}$, dwa mocne noże do cięcia chrząstki $z$ ciągłymi metalowymi uchwytami ${ }^{26}$, jeden skrobak ${ }^{27}$, dwa haki chirurgiczne i trzy anatomiczne pincety ${ }^{28}$, dwie sztuki ostrych nożyczek - jedne krótkie do prac precyzyjnych, drugie ostre, składane na guzik ${ }^{29}$, jedne nożyczki jelitowe, jeden

20 T. Waltenbacher, op.cit., s. 213.

${ }^{21}$ BA, nazwa zespołu: Informationsdienst des Reichsministers der Justiz, alt R 22/1315, k. $244 \mathrm{f}$.

${ }^{22}$ Ibidem, k. 100.

${ }^{23}$ Instytut Anatomiczny Uniwersytetu w Heidelbergu nawet w okresie wojny narzekał na podział administracyjny placówek badawczych, który teoretycznie miał być podstawą sprawiedliwej segregacji zwłok straconych więźniów na właściwe instytuty. W części zachodniej III Rzeszy tracono dużo mniej więźniów niż we wschodnich okręgach egzekucyjnych. Wobec niedoboru zgilotynowanych więźniów, naukowcy prowadzili swoje badania i dydaktykę szkolną na osobach zmarłych w przytułkach i domach opieki. W obliczu ewakuacji tych obiektów władze instytutu prosiły o dodatkowy przydział zwłok z części leworeńskiego okręgu administracyjnego. Ibidem, alt R 22/1478, k. 50.

${ }^{24}$ Konsultacji naukowej w kwestii klasyfikacji i opisu narzędzi chirurgicznych udzielił lekarz medycyny Dariusz Wojciechowski.

${ }^{25} \mathrm{~W}$ latach 30. podczas zabiegów stosowano brzytwy.

${ }^{26}$ Chondrytom.

27 Raspator.

28 Mógł to być hak Farabeufa lub hak Kochera i chirurgiczne pincety.

29 Delikatne nożyczki chirurgiczne i standardowe składane (obecnie nieznane) nożyczki chirurgiczne. 
posrebrzany cewnik, jedna duża i kilka małych chirurgicznych sond, jedno narzędzie do pośmiertnego otwarcia kręgosłupa ${ }^{30}$, jedna piła chirurgiczna na łuku lub płatnica i otwornica, skręcone kleszcze $^{31}$, jedne kleszcze do oddzielenia opon mózgowych od kości czaszkowych $^{32}$, jeden przecinak i pobijak ${ }^{33}$, jedne nożyczki do cięcia chrząstki, cztery paczki ostrych igieł i dwa kłębki szpagatowego sznurka, jedna mocna szczotka do paznokci. Całość miały dopełniać różnego rodzaju tace, czerpaki, naczynia miarowe, gumowy kitel i gąbka ${ }^{34}$. Mogłoby się wydawać, że tak szczegółowa regulacja dotycząca opisu i liczby narzędzi chirurgicznych niezbędnych do celów sekcyjnych była charakterystyczna dla ustawodawcy III Rzeszy, jednak polskie rozporządzenie Ministra Sprawiedliwości i Ministra Spraw Wewnętrznych z 15 lipca 1929 roku ${ }^{35}$ jeszcze bardziej szczegółowo regulowało kwestię wykonywania oględzin sądowo-lekarskich zwłok ludzkich i wyposażania sal prosektoryjnych.

Prawnie uregulowany podział administracyjny niemieckich instytutów anatomicznych, przypisanych do poszczególnych centralnych

${ }^{30}$ Rachiotom.

${ }^{31}$ Prawdopodobnie były to kleszcze do kręgosłupa.

32 Durazange.

33 Oseotom i młotek chirurgiczny.

${ }^{34}$ Reichsgesundheitsblatt, t. 16, wyd. 36, Berlin 1941, s. 9; T. Waltenbacher, op.cit., s. 212 .

${ }^{35}$ Dziennik Urzędowy Ministra Sprawiedliwości z 1929 roku, Nr 14, Paragraf 13 tego rozporządzenia wymienia ,jeden silny brzuszaty skalpel, jeden długi nóż sekcyjny, jeden zwykły skalpel anatomiczny, dwoje silnych szczypczyków (pincet), silne nożyczki anatomiczne, nożyce gałkowe do jelit, nożyce kostne zakrzywione, piłka do otwierania czaszki, dłuta lub dłuta do otwierania kręgosłupa, młotek, kilka zagłębników, igła silna zakrzywiona i zwitek szpagatu do zeszycia zwłok po sekcji, miara metalowa $30-50 \mathrm{~cm}$ i miara zwijana dłuższa, menzurka szklana z podziałką do $200 \mathrm{~cm}$ sz., łyżka do czerpania i gąbka, kraniometr (cyrkiel) do pomiarów głowy itp., papierki lakmusowe, niebieskie i czerwone, kilka szkiełek przedmiotowych, dwie flaszeczki na $20 \mathrm{~cm} \mathrm{sz.} \mathrm{z} \mathrm{korkiem}$ szklanym lub gumowym z 2-4\% wodnym rozczynem formolu, na skrawki do badania mikroskopowego. W razie zachodzącego podejrzenia otrucia niezbędne są nadto trzy słoje szklane około litrowej pojemności z korkami szklanymi do przechowywania narządów wewnętrznych i ich treści i dla przesłania ich do badania chemicznego". Co ciekawe, rozporządzenie to w niemal w niezmienionej treści (zastąpiono niektóre, dawne medyczne nazwy organów) stosuje się w Polsce do dziś. 
miejsc straceń wpłynął na wzrost efektywności wykorzystywania ciał ofiar III Rzeszy. Zwłoki postrzegane jako dobro gospodarki narodowej traktowano przedmiotowo, a łacińską maksymę Hic locus est ubi mors gaudet succurrere vitae ${ }^{36}$ umieszczaną zarówno przed wojną, jak i obecnie nad wejściami do instytutów anatomicznych oraz sal prosektoryjnych pozbawiono moralnego wydźwięku. Problem masowego bezczeszczenia zwłok ludzkich ubrano w pozytywistyczne ramy prawne, legalizując na oczach niemieckiego społeczeństwa ten przerażający proceder.

\section{Wykorzystywanie zwłok w jednostkach badawczych w Poznaniu i Gdańsku}

W okresie 1939-1945, wraz z nasilającą się polityką eksterminacyjną III Rzeszy na ziemiach wcielonych, większość zwłok została administracyjnie przydzielona wschodnim placówkom naukowym, w których badano i preparowano ciała ofiar pochodzące $z$ Kraju Warty. Przykładowo w poznańskim miejscu straceń w okresie od czerwca 1940 roku do sierpnia 1942 roku stracono 1196 osób. Polskie archiwa i Instytut Pamięci Narodowej nie posiadają w swoich zasobach spisów ofiar poznańskiego więzienia po 1942 roku, jednak z dużą dozą pewności liczbę zgilotynowanych i powieszonych więźniów do 1945 roku można szacować na 2500 osób ${ }^{37}$. We wrocławskim miejscu straceń stracono 869 więźniów ${ }^{38}$. W obliczu przytoczonych danych można przyjąć, że znaczna część ciał ofiar zamordowanych w tych aresztach śledczych trafiała do poznańskiego i wrocławskiego instytutu anatomicznego.

Ogromna liczba ofiar totalitarnego systemu dała naukowcom poznańskiej jednostki naukowej nieograniczony dostęp do materiału badawczego, pozwalając im realizować projekty medyczne, wspie-

${ }^{36}$ Oto miejsce, gdzie śmierć cieszy się, że może dopomóc życiu.

37 IPN Główna Komisja Ścigania Zbrodni Przeciwko Narodowi Polskiemu (dalej: GK), nazwa zespołu: wykaz osób ściętych na gilotynie w Poznaniu w latach 1940-1942, sygn. 80/4.

${ }^{38}$ IPN Wrocław (dalej: Wr), nawa zespołu: Wrocławskie więzienie przy ulicy Kleczkowskiej, sygn. 6/72/1, s. 34 pdf. 
rane przez politykę hitlerowskich Niemiec. Jak wiadomo, faszyści przywiązywali ogromną uwagę do czystości rasy i krwi. Wierzyli, że poznanie tajemnic ludzkiego ciała pozwoli stworzyć idealnych fizycznie obywateli, przewyższających siłą i zdolnościami intelektualnymi swoich wrogów. Pracujący w tej jednostce prof. Robert Herrlinger ${ }^{39}$ w swojej pracy skupił się głównie na badaniu składu ludzkiej krwi i śledziony, organu który magazynował w niewielkich ilościach osocze. Badania nad zwierzęcymi śledzionami były tematem jego przedwojennej medycznej dysertacji ${ }^{40}$. Herrlinger jeszcze przed egzekucją pobierał straceńcom krew, a po dekapitacji porównywał ją z jej pośmiertnym odpowiednikiem. Przeprowadzał również błyskawiczne sekcje zwłok, badając właściwości organów wewnętrznych po wykrwawieniu się ciała. Trzy lata po wojnie w jednej ze swoich publikacji opisywał przełom w badaniu ludzkiej śledziony, która od 30 lat nie mogła być precyzyjnie zbadana ${ }^{41}$. Dotychczasowe, zastępcze badania nad zwierzęcymi organami były błędne, ponieważ jak wskazywał profesor, morfologia ludzkiej śledziony znacznie różni się nawet od organu małpy ${ }^{42}$. Herrlinger wspierał praktykę prowadzenia badań medycznych wyłącznie na ludzkich preparatach, które jako jedyne były w stanie zapewnić wiarygodne wyniki. Opisując

${ }^{39}$ Robert Herrlinger, anatom i historyk medycyny, urodził się 14 kwietnia 1914 roku w Antwerpii, studia medyczne ukończył na Uniwersytecie w Heidelbergu, doktoryzował się na Uniwersytecie w Jenie w 1938 roku. Wraz z początkiem września 1942 roku został zatrudniony na Uniwersytecie Rzeszy w Poznaniu na stanowisku asystenta prof. Vossa, dziekana wydziału medycznego. Pracę w akademickim semestrze zimowym oficjalnie rozpoczął 1 października 1942 roku po powrocie $z$ frontu wschodniego. Herman Voss osobiście zabiegał w Ministerstwie Zdrowia o odroczenie służby wojskowej swojego asystenta. Herrlinger uzyskał tytuł doktora habilitowanego nauk medycznych 6 maja 1943 roku. Po wojnie długoletni pracownik Uniwersytetu w Jenie zmarł 8 lutego 1968 roku w Kiel.

${ }^{40}$ R. Herrlinger, Die Milzgefäbe der Wieben Ratten, Dysertacja Medyczna na Uniwersytecie w Heidelbergu ogłoszona w 1938 roku.

${ }^{41}$ Idem, Das Blut in der Milzvene des Menschen, w: Anatomischer Anzeiger, Zentralblatt für die gesamte wissenschaftliche Anatomie 96, Jena 1948. Co ciekawe, zgodę na przytoczoną publikację wyraziły władze radzieckie, kontrolujące wschodnią część powojennych Niemiec.

${ }^{42}$ Herrlinger badał śledziony różnych ssaków, takich jak: wół, pies, kot, świnia, małpa, jeż i szczur. 
metodologię badawczą stojącą za jego doświadczeniem i publikacją powoływał się na badanie ośmiu ludzkich zwłok, 40-80 sekund po wykonaniu kary śmierci ${ }^{43}$. W tak krótkim czasie po egzekucji tętnice szyjne, pulsując, usuwały z ciała większość krwi ofiary, potrzebnej do dalszych eksperymentów ${ }^{44}$. Niemiecki lekarz techniką pipetowania badał skład i rozkład pośmiertny krwi, pobierał ją bezpośrednio ze śledziony w czasie od 120 do 180 sekund po śmierci więźnia. W dalszym opisie metodologicznym naukowiec podkreślał, że wszystkie ofiary przed śmiercią były karmione tym samym rodzajem żywności i przebywały w podobnych warunkach lokalowych, co mogło mieć wpływ na budowę krwi. Herrlinger, był przekonany, że stres psychiczny kreowany przez układ nerwowy również bezpośrednio wpływał na badany organ, a za jego pośrednictwem na tkanki mięśniowe człowieka. Jak podają zapiski Hermana Vossa, Herrlinger opisywał w swoim eseju odciętą szyję więźnia jako obszar badawczy (ignorując gilotynę), z lekka traktował narzędzia chirurgiczne, a kata przedstawiał jako swojego asystenta ${ }^{45}$. Dziekan Wydziału Medycyny Instytutu Anatomicznego przy Uniwersytecie Rzeszy w Poznaniu - Herman Voss, w przeciwieństwie do swojego asystenta, nie ograniczał się do badania jednego ludzkiego organu. Preparował także zwłoki, tworząc szkielety rozsyłane na zamówienie różnych muzeów i placówek nauko-

${ }^{43} \mathrm{~W}$ obliczu tak krótkiego czasu od stracenia więźnia do badania jego zwłok Herrlinger musiał znajdować się w drugim pomieszczeniu sąsiadującym z miejscem straceń, a pomocnicy kata zapewne niezwłocznie dostarczali mu ciało ofiary. Jak wynika z zapisków naukowca, w celu pobrania organu i krwi lekarz dokonywał błyskawicznego otwarcia ciała.

44 Jak pisał Herrlinger, próbki krwi często były zanieczyszczone przez samowładne opróżnienie treści żołądkowej zdekapitowanego więźnia.

45 Co ciekawe, o obecności naukowca w pobliżu poznańskiego miejsca straceń nie informował Karol Robert Grams, pomocnik kata - Gottloba Bordta. Mimo że na swoim procesie Grams przyznał się do udziału w egzekucji ok. 200 Polaków, z jego ust nie padły żadne słowa o eksperymentach medycznych, prowadzonych na zwłokach straconych więźniów, skazywanych na śmierć głównie za nielegalny ubój zwierząt hodowlanych, kradzież paczek frontowych i uderzenie obywatela pochodzenia niemieckiego. IPN GK, nazwa zespołu: Sąd Apelacyjny w Poznaniu, akta sprawy K.R. Grams, sygn. 224/26 - IPN Poznań (dalej: PO), sygn. 792/19. 
wych. Najprawdopodobniej to właśnie on przysłał wspomniane na początku artykułu „czaszki podludzi” do wiedeńskiego Muzeum Historii Naturalnej ${ }^{46}$. Jego udział w procesie pozyskiwania kości Polaków potrzebnych do konstruowania modeli anatomicznych pośrednio potwierdza w swoich opisach Feliks Jankowiak, który podczas wojny pracował w poznańskich wodociągach ${ }^{47}$. Pewnego wieczora, zadzwonił do niego oburzony Hermann Voss, domagając się natychmiastowej interwencji, ponieważ jego laborant po wypiciu wody $z$ kranu stracił przytomność z powodu nagłego zatrucia. W trakcie oględzin instalacji wody w Instytucie Anatomicznym w Poznaniu okazało się, że na czwartym piętrze budynku kadzie do maceracji ludzkich tkanek ${ }^{48}$, w których gotowano ciała, zostały na stałe podłączone gumowym wężem do instalacji hydraulicznej budynku, co w przypadku nagłego spadku ciśnienia w miejskiej instalacji wodociągowej powodowało zasysanie do niej zawartości kadzi, zakażając zdrową wodę niebezpiecznymi ptomainami ${ }^{49}$. Jak wspomina Jankowiak, Voss, wygrzewając się na balkonie, pisał w swoim pamiętniku: „Na prawo i lewo ode mnie leżały bielące się kości Polaków, które od czasu do czasu leciutko trzeszczały"50. Wybielone kości doskonale nadawały się do konstruowania szkieletów anatomicznych, rozsyłanych przez hitlerowskiego profesora do gabinetów ras licznych muzeów europejskich.

Z kolei Akademia Medycyny Praktycznej w Gdańsku powołana do życia w 1935 roku na gruntach szpitala miejskiego, pod koniec 1940 roku uzyskała prawo pełnego kształcenia studentów medycyny w zakresie przedmiotów klinicznych i przedklinicznych. Na przełomie 1939 i 1940 roku rektor Gdańskiej Państwowej Akademii Medycznej, Erich Grossmann, zaproponował niemieckiemu wybitnemu prof. Rudolfowi Spannerowi przeniesienie się z Kolonii do

${ }^{46}$ Voss za każdą spreparowaną czaszkę pobierał opłatę w wysokości 25 RM.

${ }^{47}$ F. Jankowiak, W hitlerowskim zakładzie „naukowym”, „Kronika Miasta Poznania” 1976, 10/12, R. 44, nr 4, s. 49-53.

48 Proces maceracji służył oddzielaniu układu kostno-szkieletowego od miękkich tkanek ciała.

${ }^{49}$ Ptomainy - potocznie nazywane jadem trupim.

${ }^{50}$ F. Jankowiak, op.cit., s. 52. 
Gdańska i zorganizowanie w nim instytutu anatomicznego. Wkrótce kadrę naukową akademii zasilili także prof. dr Otto Schmidt, prof. dr Max Schneider, prof. dr Werner Koll ${ }^{51}$. Działalność naukowo-dydaktyczna Instytutu Anatomicznego obejmowała swoim obszarem liczne wykłady oraz zajęcia praktyczne dostępne dla stale rosnącego grona studentów medycyny, urozmaicone licznymi pomocami dydaktycznymi i bogatymi preparatami poglądowymi, do tworzenia których wykorzystywano głównie zwłoki ofiar straconych w Królewcu. Ciała te przekazywano w celu prowadzenia kursów preparacyjnych, mikroskopowych oraz kształcenia starszych studentów w zabiegach chirurgicznych ${ }^{52}$. $\mathrm{Z}$ czasem, w obliczu stale rosnącej grupy studentów medycyny, liczba zwłok dostarczanych przez centralne miejsce straceń w Królewcu i Gdańsku okazała się niewystarczająca. Profesor Spanner, organizując kolejne kursy anatomiczne, zwracał się z licznymi prośbami o zwłoki do dyrekcji wspomnianego już wcześniej szpitala w Kocborkowie. Poważne problemy z zaopatrywaniem gdańskiego instytutu anatomicznego okazały się przyczyną nawiązania współpracy z jego poznańskim odpowiednikiem. Ponieważ pomorska placówka miała ograniczone racje paliwowe, nie była w stanie dla jednego lub dwóch ciał samodzielnie wysyłać ciężarówki, wobec tego kierownicy obu instytutów zawarli porozumienie, na mocy którego patolodzy i anatomowie poznańscy zabezpieczali zwłoki (preparowali je), by późnej po uprzedzeniu partnera wysłać transport kilku przygotowanych ciał ${ }^{53}$. Rudolf Spanner, poza zajęciami dydaktycznymi i licznymi zabiegami zmierzającymi do zabezpieczenia materiałów badawczych i poglądowych dla swoich studentów, prowadził własne badania nad fibroiną starzejącego się łożyska oraz szczegółowymi stosunkami panującymi w układzie krążenia gruczołów ślinowych, skóry, gałki ocznej, ozębnej, unaczynienia odbytnicy i nad mechanizmem

${ }^{51}$ M. Tomkiewicz, P. Semków, op.cit., s. 25.

52 IPN OK Gd., sygn. S 74/02/Zn, t. 9, k. 1729.

53 BA, nazwa zespołu: Informationsdienst des Reichsministers der Justiz, alt R 22/1478, k. 27f. Współpraca pomiędzy opisanymi instytutami dowodzi nadwyżek materiałów badawczych znajdujących się w Poznaniu, co z pewnością nie pozostawało bez związku z dużą liczbą egzekucji wykonywanych w tym miejscu. 
regulacji układu limfatycznego ${ }^{54}$. W obliczu nasilających się działań wojennych i wzrastającej liczby poszkodowanych żołnierzy, Spanner we współpracy z prof. Heinrichem Klose, dyrektorem Kliniki Chirurgicznej, opracował modelowe procedury operacyjne dla ciężko rannych, które demonstrowano na przykładzie licznych zabiegów na zwłokach znajdujących się w placówce badawczej ${ }^{55}$. Podobnie jak w Poznaniu, Gdański Instytut Anatomiczny preparował szkielety $z$ dostarczonych mu ciał metodą maceracji oraz prowadził eksperymenty medyczne $z$ krwią więźniów i różnymi chorobami, ucząc na nich wojskowych lekarzy ${ }^{56}$.

\section{Wykorzystywanie zwłok do produkcji mydła w Gdańsku}

Wraz z szybkimi postępami wojsk Armii Czerwonej, następował gwałtowny i chaotyczny proces ewakuacji niemieckich urzędów i placówek badawczych. Próby zatarcia przez hitlerowców śladów ogromu swej zbrodniczej działalności nie były w pełni możliwe. W marcu obiekty Gdańskiej Akademii Medycznej zajęli Rosjanie, tworząc w nich wojskowy kompleks szpitalny. Wraz z oględzinami ich pomieszczeń dokonano przerażającego odkrycia. Liczne szczątki ludzkie i kości zalegały w salach placówki naukowej. W maceratorium, w otoczeniu odpreparowanej skóry ludzkiej znaleziono kilka

${ }^{54}$ M. Tomkiewicz, P. Semków, op.cit., s. 45.

55 IPN OK Gd., sygn. S 74/02/Zn, t. 4, k. 616.

56 IPN GK, nazwa zespołu: United Nations War Crimes Commission. Delegat Polski do Komisji Narodów Zjednoczonych do spraw Zbrodni Wojennych, tytuł teczki „Materiały w sprawie eksperymentów przeprowadzanych w Instytucie Anatomicznym w Gdańsku nad wyrobem mydła z tłuszczu ludzkiego”, sygn. $161 / 22$, s. 17,28 . Obecny stan wiedzy nie pozwala jednak na całkowite potwierdzenie tej tezy. Autorzy publikacji Profesor Rudolf Spanner 1895-1960 stwierdzają wszakże, że do badań nad tyfusem plamistym i durem brzusznym, dziesiątkującym wojska niemieckie podczas wojny, na wyraźne polecenie władz III Rzeszy przystąpiły różne placówki naukowe, prowadząc swoje eksperymenty na więźniach obozów zagłady, jednak z całą stanowczością nie można było potwierdzić takiego zaangażowania Gdańskiej Akademii Medycznej i Instytutu Anatomicznego. 
kawałków substancji przypominającej surowe mydło. Wkrótce odkryto również pochodzenie maszyn wykorzystywanych do produkcji mydła. Zainstalowała je na przełomie marca i kwietnia 1942 roku gdańska firma Aird, gromadząc uprzednio przygotowane części w piwnicach miejskiej politechniki, skąd również pochodzili pracownicy oddelegowani do zamontowania urządzeñ ${ }^{57}$. Na skutek licznych zawiadomień obywateli miasta Gdańsk, 12 maja 1945 roku w ratuszu miejskim w obecności szerokiej komisji składającej się z przedstawicieli polskiego rządu, gdańskich urzędników i prokuratorów, przesłuchano tymczasowo aresztowanego Zygmunta Mazura. Dwudziestopięcioletni podejrzany zeznał: „rozpocząłem pracę w Instytucie Anatomicznym w Gdańsku w dniu 17 stycznia 1944 r., jako laborant. Przez pierwsze sześć tygodni odbyłem kurs, z powodu braku specjalnych szkół, gdyż ukończyłem tylko sześć klas gimnazjum w Gdańsku. Po sześciu tygodniach kierownik Instytutu prof. Spanner zatrzymał mnie jako jego osobistego pomocnika, potrzebnego szczególnie do przygotowywania materiałów do książki, którą pisał. Co tyczy się kwestii produkcji mydła, prof. Spanner jesienią 1943 r. rozkazał pozyskiwać tłuszcz z ciał, preparowanych przez studentów i w lutym 1944 r. zacząłem wraz z von Bargen[em] i dwójką innych pracowników pod okiem nadzorcy, wykonywać w głównym laboratorium pierwszą część procesu produkcji mydła z ludzkiego tłuszczu. Prof. Spanner uzyskał recepturę na produkcję mydła od swojej asystentki, Keuteck. Była to domowa receptura, którą dla Instytutu Anatomicznego Akademii Medycznej 15 lutego przetłumaczono na język niemiecki [...] W lutym 1944 r. zaczęliśmy produkcję mydła z $75 \mathrm{~kg}$ ludzkiego tłuszczu, z czego otrzymaliśmy mydło o wadze ok. $10 \mathrm{~kg}$, ale jego wagi nie jestem w stanie stwierdzić, gdyż go nie ważyłem. Produkcja mydła trwała około tygodnia. Prof. Spanner zamknął całość zapasu w swoim pokoju i nie wiem, co dokładnie $z$ nim zrobił. Produkcję wstrzymano do czasu, gdy

${ }^{57}$ Ibidem, s. 72, 73 pdf. Jak wynika z zeznań świadków, maszyny te służyły do ogrzewania kadzi, w których ciała po zmieszaniu ich z odczynnikiem ulegały oddzieleniu na kości i tkanki miękkie. Cały proces miał trwać 24 h. Powstałe w ten sposób pochodne mydeł, służyły w salach sekcyjnych do czyszczenia tablic naukowych. 
w tym samym roku na rozkaz prof. Spannera podjęto proces na nowo. Zaczęliśmy ponownie zbierać ludzki tłuszcz z preparowanych ciał. W styczniu 1945 r. prof. Spanner opuścił Gdańsk, nakazując nam użycie całego zapasu tłuszczu w produkcji mydła stosownie do ostatniej receptury. Na początku czułem wstręt do tego mydła, lecz później używałem go. Wziąłem kawałek do domu, i moja rodzina użyła go do prania ubrań. Co do ciał, pochodziły one $z$ różnych obozów koncentracyjnych na Pomorzu, ale zazwyczaj z obozu Stutthof, obok Gdańska, i także z Elbląga, przytułków i więzienia w Gdańsku. Ciała przysyłane $z$ więzienia po egzekucji były bez głów. Raz zamówiliśmy transport 30 Polaków, których rozstrzelano w Bydgoszczy. Prof. Spanner korespondował z wszystkimi więzieniami i obozami na Pomorzu, prosząc je o przysyłanie mu tyle ciał, ile tylko dadzą radę dostarczyć. Przez okres pierwszego roku pracowało tam ok. 15 studentów, których liczba później urosła do 400. Osobowa ewidencja każdego ciała była szczegółowo prowadzona. Polacy w niej dominowali, były tam także ciała niemieckich żołnierzy skazanych na śmierć i radzieccy jeńcy wojenni, a także duża liczba kobiet $z$ domów dla osób obłąkanych, przytułków i więzień. Wszystkie ciała były przywożone przez von Bargena, ponieważ tylko on miał wyłączne prawo jazdy samochodem. Ja również kilka razy byłem wysyłany po zwłoki. Do czasu pracy studentów nad fabrykacją mydła była to tajemnica tego Instytutu, jednak wkrótce i oni uczestniczyli w niej i uczyli się, współpracując $z$ nami. O ile mi wiadomo, proces produkcyjny mydła w Instytucie znał tylko prof. Spanner, von Bergen, asystentka Keuteck, ja i sierżant Herbert Labusch [...], a również dr W [nieczytelne], ćwiczeniowiec i asystent prof. Spannera. Nie jestem w stanie nic stwierdzić, czy Hektor Grossmann wiedział o fabrykacji mydła, czy też nie i czy fabrykacja była zarządzona przez władze niemieckie lub milicyjne, czy była to samodzielna koncepcja prof. Spannera. [...] Prof. Spanner chodził tam (do nowo postawionego budynku) i robił szkielety - proszę zanotować - że nie jeden szkielet zrobił. Niektóre ciała były przecinane na dwie połowy, w jakim celu - nie wiem, ciała mrożono w temperaturze 20 stopni poniżej zera i chowano w specjalnej maszynie. Potwierdzam także, że bezużyteczne części ciała lub kości palono w nocy na rozkaz władz policyjnych w związku z rozchodzącym się okropnym zapachem 
spalenizny. Oświadczam, że podczas wygotowywania części zwłok tłuszcz się gromadził, jednak nie używaliśmy go do produkcji mydła. Fabrykacja mydła była robiona tylko dwa razy i tylko $z$ tłuszczu zdrapanego przez studentów podczas ich pracy. Mydło to miało osobliwy zapach i słyszałem, jak prof. Spanner chciał koniecznie dodać jakichś chemikaliów dla nadania mu migdałowej woni [...] nie wiem, gdzie obecnie znajduje się prof. Spanner. Jego ostatni adres znany w Instytucie był Anatomiczny Instytut Halle w Saale"58.

Pod wpływem przerażających zeznań udzielonych przez Mazura Komisja Narodów Zjednoczonych - Spraw Zbrodni Wojennych - delegatura w Polsce 15 maja 1945 roku postanowiła skompletować zespół delegatów, powierzając im zadanie przeprowadzenia oględzin w budynkach Gdańskiego Instytutu Anatomicznego ${ }^{59}$. W skład tego zespołu weszli reprezentanci Głównej Komisji Śledczej Zbrodni Niemieckich w Polsce: Stanisław Janusz - wicepremier Polskiego Rządu i przewodniczący Komisji, deputowana Zofia Nałkowska - wiceprzewodnicząca, deputowany Jerzy Kornacki - dyrektor Instytutu Pamięci oraz Sekretarz Prezydium Komisji, deputowana Helena Boguszowska-Kornacka, Edmund Zaleski ${ }^{60}$ - minister kultury i sztuki, Józef Kandel - szef Departamentu Ministerstwa Sprawiedliwości, deputowany dr Andrzej Gustaw Raciążek, Adolf Dąb - prokurator delegowany z Ministerstwa Sprawiedliwości. Stronę radziecką reprezentowali: gen. Siemon Mikulski - komendant miasta Gdańsk i Dystryktu Gdańsk, płk Stefan Krutij - asystent oficera politycznego dla miasta Gdańsk, płk Sergiusz Sołowiew - reprezentant 43 armii, kpt. Nikołaj Adaczew - doradca w dowództwie Gdańska, mjr dr Jelanski - superintendent w wojskowym szpitalu. $Z$ ramienia biura policji prowincji Gdańsk oddelegowani zostali: płk Grzegorz Korożyński - dyrektor biura policyjnego w Gdańsku, por. Edward

58 Ibidem, sygn. $161 / 22$, s. 8-11 pdf. Inne zeznania świadka Aleksego Opalińskiego sugerują, że palenie zwłok odbywało się zarówno w dzień, jak i w nocy. Dodatkowo podczas pracy w Instytucie przedstawiono mu do porównania próbki mydła, z których jedno miało kolor biały, drugie żółty, a trzecie brązowy. Ibidem, s. 11-13 pdf.

59 Od marca 1945 roku powołano trzy komisje dokonujące oględzin pomieszczeń Akademii Medycznej w Gdańsku.

${ }^{60} \mathrm{~W}$ dokumencie błędnie wpisano nazwisko, powinno być Edmund Zalewski. 
Forst - szef policyjnego biura śledczego na prowincję Gdańsk, płk Iwan Sieniczkin - doradca WUBP w Gdańsku. Władze miasta Gdańsk reprezentował: Franciszek Kotus-Jankowski - prezydent Gdańska, Franciszek Chudoba - wiceprezydent Gdańska, Władysław Niewiadomski - wiceprezydent Gdańska, dr Antoni Jamiński pierwszy lekarz miejski w Gdańsku. Prasę polską reprezentował: Stanisław Strabski - dyrektor sekcji marynarki Polpressu ${ }^{61}$. Po skompletowaniu wszystkich członków, Komisja udała się na róg alei Dellbruck i Adolf Hitler Str. (w momencie tworzenia raportu aleja Marszałka Rokossowskiego), gdzie znajdował się kompleks budynków należących do Instytutu Anatomii zrzeszonego z Instytutem Higieny - dawnej Akademii Medycznej w Gdańsku. Budynki tych placówek badawczych, jak podaje raport, były odseparowane od ulicy wysokim murem z czerwonej cegły. W piwnicach obiektów należących do Instytutu, znajdowały się duże pomieszczenia. W pierwszym $z$ nich znaleziono 10 znacznych rozmiarów kadzie zawierające ludzkie zwłoki. W trzech $z$ nich znajdowały się wyłącznie ciała bez głów, w kolejnych trzech duża liczba kompletnych ciał, a w pozostałych czterech kadziach odseparowane części ludzkich zwłok i ludzka skóra. W tym samym pomieszczeniu były mniejsze kadzie zawierające głowy noszące ślady ran i wielu urazów62. Jak stwierdziła Komisja, zwłoki były zakonserwowane w alkoholu i kwasie karbolowym ${ }^{63}$.

W drugim pomieszczeniu znajdowało się osiem kadzi, które były puste lub w trakcie budowy. W hali preparatoryjno-anatomicznej opisano trzy kadzie korpusów ciał, przy czym w jednej z nich

${ }^{61}$ Rządowa agencja prasowa utworzona w Moskwie w 10 marca 1944 roku przez Związek Patriotów Polskich, w lipcu siedzibę Polpressu przeniesiono do Łodzi, a następnie do Warszawy. Podległa bezpośredniemu kierownictwu ZPP i dowództwu wojskowemu Ludowego Wojska Polskiego. Agencja wydawała biuletyny w Moskwie i w Polsce, informowała społeczeństwa polskie o rozwoju sytuacji na froncie, życiu w kraju i za granicą. Jej zadaniem było także informowanie zagranicy o życiu polskim. Agencja posiadała sieć oddziałów krajowych i zagranicznych (Moskwa, Nowy Jork). Nadzór nad Polpressem sprawował Minister Informacji i Propagandy.

62 Ibidem, s. 4 pdf.

${ }^{63}$ Ibidem, s. 5 pdf. 
były wyłącznie zwłoki kobiet. W toku dalszych prac inspekcyjnych stwierdzono, że na terenie Instytutu postawiono nowy budynek. W jego wnętrzu członkowie komisji odkryli metalową kadź wypełnioną płynem, w której pływały strzępy ciał, dwa sterylizatory używane zapewne do gotowania tłuszczu, dużą skrzynię wypełnioną pozbawioną tkanki tłuszczowej ludzką skórą, szafkę $\mathrm{z}$ resztkami ludzkich kości (udowych i czaszkowych, mających również cechy typu mongolskiego). Na jednej z półek tej szafy stały szklane słoiki z sodą kaustyczną, a w murze ściany znajdowała się dodatkowa, przemyślna szafka, skrywająca inne chemiczne preparaty do oddzielania resztek ciał od kości lub produkcji mydła. Na blacie stołu obserwatorzy znaleźli $2 \mathrm{~kg}$ nieskończonego mydła $\mathrm{z}$ pierwszego warzenia i kilka metalowych form. W pomieszczeniu tym stał również piec, służący do palenia kości. Dwie czarne tablice wiszące na ścianach zawierały napis cyfrowy:
1. 11.XII.44-kl
7.XII.44 - gr
12.XII.44
2. 6.V.44. - 3a. $75^{64}$

Tuż obok nich znajdował się duży pojemnik do testów, z którego wystawał termometr. Na poddaszu nowego pomieszczenia odkryto dużą liczbę ludzkich kości i czaszek.

W podsumowaniu protokołu znajduje się informacja o złożonych przez członków podpisach i dacie jego powstania, tj. 15 maja 1945 roku $^{65}$.

Jak wskazują ponownie przeanalizowane materiały dowodowe zebrane w 1945 roku, nie istnieją niepodważalne przesłanki pozwalające stwierdzić, że w Gdańsku podczas II wojny światowej produkowano mydło z ludzi w skali przemysłowej ${ }^{66}$.

${ }^{64}$ Ibidem, s. 6 pdf.

65 Ibidem, s. 7 pdf.

66 Zgromadzone w toku prac śledczych dowody w postaci kawałków ludzkiej skóry i substancji podobnej do mydła jesienią 1945 roku przesłano do Instytutu Ekspertyz Sądowych w Krakowie, który jednoznacznie wskazał, że substancje te są mydłami, jedno w stanie wykończonym, a drugie surowym, jednak z powodu chemicznych reakcji towarzyszących procesowi jego powstawania nie ma możliwości stwierdzenia w nim białek pochodzenia ludzkiego. M. Tomkiewicz, P. Semków, op.cit., s. 93. Wznowione po latach śledztwo prokuratorów IPN, zmierzające do ostatecznego potwierdzenia lub zaprzeczenia ustaleń Głównej 
Niestety nie posiadamy w zebranej dokumentacji liczby ciał, które dostarczono do Instytutu Anatomicznego w Gdańsku. Z zeznań świadków wynikało, że rejestry te były skrupulatnie prowadzone:

„Jak wynika $z$ dobrowolnego oświadczenia Ericha Graesa Ld. 1141 Krim. Dir Erich Graes stworzonego na potrzeby określenia przeprowadzania egzekucji w Gdańsku wyróżniono:

a) egzekucje osób $z$ wyrokami śmierci zapadłymi przed sądami cywilnymi,

b) żołnierzy Wehrmachtu skazanych na śmierć przez sądy wojskowe,

c) członków SS i Policji skazanych na śmierć przez sądy SS i policyjne.

Ad a) Osoby te były stracone przez gilotynę. Od początku $1944 \mathrm{r}$. osoby skazane przez cywilne sądy były przetransportowane do zakładu karnego w Królewcu, gdzie wszystkie wyroki z terenów wschodnich były przeprowadzane. Od początku 1944 r. przewodniczący egzekutywy miał siedzibę w tym więzieniu. Dodatkowo od początku 1944 r. więzienie karne w Gdańsku było miejscem wykonywania wszystkich zapadłych wyroków śmierci w dzielnicy gdańsko-zachodniopruskiej i części wschodniej Pomorza z Gdańskiem włącznie. Zakładam, $z$ całą stanowczością, że ostatnie z pośród wielu ciał będących do dyspozycji Instytutu Anatomicznego na medyczne zajęcia dydaktyczne w liceum medycznym w Gdańsku [nieczytelne], pozostawały tam w celach naukowych.

Komisji Badania Zbrodni Niemieckich w Polsce, mimo rozwoju nauki, nie przyniosło jednoznacznych odpowiedzi, bowiem zbadane ponownie mydło mogło pochodzić z procesu maceracji zwłok w obecności zasady sodowej lub potasowej. Jedynym wątpliwym argumentem przedstawionym przez prof. Stołyhwę ponownie badającego przywiezione $z$ Norymbergii próbki mydła, przemawiającym za świadomą i zamierzoną produkcją mydła przez zespół prof. Spannera była śladowa ilość kaolinu zawarta w znalezionych przebadanych kawałkach, która miała nadawać mu większej ścierności. Jednak, mając na uwadze fakt, że Spanner wykorzystywał kaolin w procesach konserwacyjnych zwłok, które nim przez długi czas przesiąkały i w dalszym okresie były poddawane zmiękczaniu (maceracji), można podważyć najnowszą argumentację zwolenników tej teorii, bowiem uzyskane w procesie maceracji zwłok pochodne mydła były mimowolnie zanieczyszczone kaolinem. 
Ad b) Żołnierze byli traceni przez rozstrzelanie. W sprawie tych zwłok, ja nie jestem w stanie udzielić jakichkolwiek informacji, zgodnych $\mathrm{z}$ moją wiedzą. Również i w tym przypadku zakładam wykorzystanie ciał pozostających w dyspozycji do celów naukowych.

Ad c) O ile wiem, te wyroki śmierci były wykonywane przez rozstrzelanie w aresztach SS i Policji ustalonych w Gdańsku-Matzkau. Nie posiadam wiedzy, czy zwłoki te były palone czy przekazywane do dyspozycji Instytutu Anatomicznego. Ostatnia z tych możliwości nie jest wykluczona.

Prawdę mówiąc, nie posiadam wiedzy, czy ciała lub ich części były przesyłane $z$ Instytutu Anatomicznego i przenoszone do dyspozycji jakiejś fabryki dla celów produkcji jakichkolwiek preparatów. Nie ma wątpliwości, że w Gdańsku istniała specjalna drużyna, która zabijała, strzelając. Jest to wystarczająco dowiedzione poprzez zastrzelenie czterech brytyjskich oficerów lotnictwa, co miałem okazję stwierdzić na piśmie [...]"67.

Mając na względzie przytoczone oświadczenie i znaczne zapotrzebowanie placówki badawczej na materiały sekcyjne, można uznać że znaczna część zwłok osób straconych w zachodniej części Prus Wschodnich i dzielnicy pomorskiej wykorzystywana była do celów badawczych Instytutu Anatomicznego w Gdańsku.

\section{Podsumowanie}

Po zakończeniu działań wojennych nadszedł czas rozliczenia zbrodni hitlerowskich w Europie. Powołany do tego celu Trybunał w Norymberdze osądził także wybranych lekarzy III Rzeszy, pracujących i eksperymentujących w obozach koncentracyjnych. Zarzutów ludobójstwa uniknęli wszyscy naukowcy pracujący w instytutach anatomicznych w Poznaniu i Gdańsku, korzystali oni bowiem głównie $z$ ciał więźniów pomordowanych w centralnych miejscach straceń i obozach zagłady. Nie udowodniono im bezpośredniego związku ze zbrodniami hitlerowskimi. Problematyka badań medycznych

67 Ibidem, s. 133, 134 pdf. 
prowadzonych w okresie II wojny światowej na całym obszarze Niemiec budzi do dziś poważne kontrowersje. $Z$ jednej strony wielcy naukowcy, którzy otrzymywali m.in. nominacje do nagrody Nobla z dziedziny medycyny ${ }^{68}$, publikujący dla wielu prestiżowych (nawet zachodnich) medycznych czasopism zagranicznych, pragnący sukcesów i pogłębiania swojej wiedzy, w pełni wykorzystali okazję, jaką dała im polityka hitlerowskiej III Rzeszy, do realizacji swoich naukowych planów i celów. Nie można też pozbawiać wielu z nich poczucia obowiązku, które z pewnością towarzyszyło ich pracy. Proces norymberski sprawił, że w gronie oskarżonych znalazł się kwiat niemieckich naukowców, którym w znacznej części nie udowodniono jednak winy lub jakiegokolwiek związku ze zbrodniami przeciwko ludzkości. Dziś uważa się, że dowody zgromadzone w sprawie produkcji mydła $z$ tłuszczu ludzkiego przez Instytut Anatomiczny w Gdańsku są niewystarczające do postawienia prof. Spannerowi zarzutu świadomej jego produkcji, gdyż wiele świadczy o tym, że był to proces uboczny, przy maceracji zwłok. Odnosząc się do samego wykorzystywania zwłok ludzkich do celów badawczych, należy zaznaczyć, że traktowanie ofiar i ich rodzin w sposób przedmiotowy, często pozbawiając krewnych prawa pochowania swoich bliskich, oraz bezczeszczenie ciał w wyniku przeprowadzania na nich licznych zabiegów, bez zgody następców prawnych, stało się możliwe na skutek polityki i instrumentalnego charakteru prawa faszystowskich Niemiec. W myśl formuły Gustawa Radbrucha lex iniustissima non est lex, prawo drastycznie łamiące podstawowe zasady moralne nie może być podstawą usprawiedliwienia niegodziwych czynów, ponieważ nie obowiązywało w momencie ich popełniania. Formuła ta stworzona na potrzeby procesu norymberskiego stała się przesłanką do skazania zbrodniarzy wojennych. Mając na uwadze fakt, że nie znalazła ona zastosowania wobec części naukowców III Rzeszy uniewinnionych w procesie, należy przyjąć, że nie dopuścili się oni zbrodni przeciwko ludzkości, a ich winę oceniać można w kategoriach moralnych. Badania tych wybitnych profesorów $z$ dziedziny medycyny przyczyniły się do stworzenia najdoskonalszych atlasów

${ }^{68}$ W 1939 roku nominację do tej nagrody otrzymał prof. Spanner. 
anatomicznych, które nieświadomie przez lata stosowano na całym świecie ${ }^{69}$.

\section{STRESZCZENIE}

Wykorzystywanie zwłok więźniów do badań w instytutach anatomicznych w III Rzeszy

W artykule opisano sposób korzystania z ciał więźniów do badań przez naukowców z Trzeciej Rzeszy. Instytuty anatomiczne w latach 1939-1945 uzyskały nieograniczony dostęp do ciał ludzkich zasobów. Podstawowym źródłem preparatów byli więźniowie. Dla celów gospodarki narodowej III Rzeszy wszystkie korpusy zostały pozbawione ochrony prawnej. Jednocześnie Ministerstwo Sprawiedliwości III Rzeszy przyjęło rozporządzenie standaryzacji wyposażenia sal sekcyjnych. Ta sytuacja dała szansę niemieckim naukowcom do realizacji praktycznie wszystkich projektów badawczych. Niektóre $z$ tych projektów, takich jak mydło z ludzkiego tłuszczu, były przedmiotem dalszych badań przeprowadzonych przez Komisję Zbrodni Wojennych ONZ.

Słowa kluczowe: więźniowie, badania anatomiczne, III Rzesza.

\section{SUMMARY}

\section{Exploatation corpses of prisoners to research by third Reich anatomical institutes}

The article describes the process of using prisoners' bodies for research by scientist of Third Reich. Anatomical institutes which before the Second World War trained medical students on the basis of few human preparation, between 1939-1945 gained unlimited access to resources of human bodies.

${ }^{69}$ E. Pernkopf, Topographische Anatomie des Menschen, Wien 1943; H. Voss, R. Herrlinger, Taschenbuch der Anatomie, Jena 1948. Po wybuchu skandalu związanego $\mathrm{z}$ badaniami zwłok zamordowanych więźniów, będących podstawą tych wspaniale ilustrowanych atlasów, znaczna część środowisk naukowych w obliczu przedstawionych dowodów zrezygnowała $z$ pracy na tych materiałach dydaktycznych. 
The primary source of preparations were prisoners' decapitated bodies. For the purposes of the national economy Third Reich all corps were deprived of a legal protection. At the same time the Ministry of Justice of Third Reich adopted a regulation which standardized the equipment of dissectingrooms. This situation had given a chance to German scientist to pursue practically all research projects. Some of these project like receiving soap from human fat was the subject of a future investigation conducted by United Nations War Crimes Commission.

Keywords: corps, prisoners, anatomical studies, third Reich.

\section{BIBLIOGRAFIA}

Gerould D., Historia gilotyny. Legenda i morat, tłum. A. Kruczkowska, Gdańsk 1996.

Herrlinger R., Das Blut in der Milzvene des Menschen, w: Anatomischer Anzeiger, Zentralblatt für die gesamte wissenschaftliche Anatomie 96, Jena 1948.

Jankowiak F., W hitlerowskim zakładzie „naukowym”, „Kronika Miasta Poznania” 1976, 10/12, R. 44, nr 4.

Kłodziński S., Z zagadnień „gospodarczej” eksploatacji zwłok ludzkich $w$ Niemczech hitlerowskich, „Przegląd Lekarski” 1964, nr 1.

Tomkiewicz M., Semków P., Profesor Rudolf Spanner 1895-1960, Naukowiec w III Rzeszy, Gdynia 2010.

Waltenbacher T., Zentrale Hinrichtungsstätten, Der Vollzug der Todesstrafe in Deutschland von 1937-1945. Scharfrichter im Dritten Reich, Berlin 2008.

AP Gd., Państwowy Szpital dla Nerwowo i Psychicznie Chorych w Starogardzie Gdańskim Kocborkowie, sygn. 2830/163.

Bundesarchiv, nazwa zespołu: Informationsdienst des Reichsministers der Justiz, alt R 22/1070.

Bundesarchiv, nazwa zespołu: Informationsdienst des Reichsministers der Justiz, alt R 22/1315.

Bundesarchiv, nazwa zespołu: Informationsdienst des Reichsministers der Justiz, alt R 22/1317.

Bundesarchiv, nazwa zespołu: Informationsdienst des Reichsministers der Justiz, alt R 22/1318.

Bundesarchiv, nazwa zespołu: Informationsdienst des Reichsministers der Justiz, alt R 22/1478.

IPN Gk., nazwa zespołu: wykaz osób ściętych na gilotynie w Poznaniu w latach 1940-1942, sygn. 80/4. 
IPN Gk, nazwa zespołu: United Nations War Crimes Commission. Delegat Polski do Komisji Narodów Zjednoczonych do spraw Zbrodni Wojennych, tytuł teczki: „Materiały w sprawie eksperymentów przeprowadzanych w Instytucie Anatomicznym w Gdańsku nad wyrobem mydła z tłuszczu ludzkiego", sygn. 161/22.

IPN Ok Gd., sygn. akt S 74/02/Zn.

IPN Po, nazwa zespołu: Sąd Apelacyjny w Poznaniu, akta sprawy K.R. Grams sygn. $792 / 19$.

IPN Wr, nawa zespołu: Wrocławskie więzienie przy ulicy Kleczkowskiej, sygn. 6/72/1. 